\title{
DIURNAL EXPRESSION OF CLOCK GENES IN PINEAL GLAND AND BRAIN AND PLASMA LEVELS OF MELATONIN AND CORTISOL IN ATLANTIC SALMON PARR AND SMOLTS
}

\author{
Tien-sheng Huang, ${ }^{1}$ Peter Ruoff, ${ }^{2}$ and Per G. Fjelldal ${ }^{3}$ \\ ${ }^{1}$ National Institute of Nutrition and Seafood Research (NIFES), Bergen, Norway \\ ${ }^{2}$ Centre for Organelle Research, University of Stavanger, Stavanger, Norway \\ ${ }^{3}$ Institute of Marine Research (IMR), Matredal, Norway
}

In Atlantic salmon, the preadaptation to a marine life, i.e., parr-smolt transformation, and melatonin production in the pineal gland are regulated by the photoperiod. However, the clock genes have never been studied in the pineal gland of this species. The aim of the present study was to describe the diurnal expression of clock genes (Per1-like, Cry2, and Clock) in the pineal gland and brain of Atlantic salmon parr and smolts in freshwater, as well as plasma levels of melatonin and cortisol. By employing an out-of-season smolt production model, the parr-smolt transformation was induced by subjecting triplicate groups of parr to 6 wks (wks 0 to 6) under a $12 \mathrm{h:12}$ h lightdark (LD) regime followed by 6 wks (wks 6 to 12) of continuous light (LL). The measured clock genes in both pineal gland and brain and the plasma levels of melatonin and cortisol showed significant daily variations in parr under LD in wk 6, whereas these rhythms were abolished in smolts under LL in wk 12. In parr, the pineal Per1-like and Cry2 expression peaked in the dark phase, whereas the pineal Clock expression was elevated during the light phase. Although this study presents novel findings on the clock gene system in the teleost pineal gland, the role of this system in the regulation of smoltification needs to be studied in more detail. (Author correspondence: ti.hu@hotmail.com)

Keywords Atlantic salmon; Brain; Clock gene; Cortisol; Melatonin; Pineal gland

\section{INTRODUCTION}

The pineal organ is the first photosensitive organ to differentiate, being a part of the central nervous system that is formed by an evagination of the epithalamus of the diencephalon in the embryo of Atlantic salmon

Submitted April 19, 2010, Returned for revision May 14, 2010, Accepted July 27, 2010

Address correspondence to Dr. Tien-sheng Huang, National Institute of Nutrition and Seafood Research (NIFES), P. O. Box 2029 Nordnes, N-5817 Bergen, Norway. Tel: (47) 98857588; Fax: (47) 55905299; E-mail: ti.hu@hotmail.com 
(Salmo salar L.) (Ekstrom, 1997). Its location just beneath the semitransparent pineal window ensures optimal photoreception, and information about daylength is conveyed to peripheral organs through its synthesis and secretion of the time-keeping hormone melatonin into the blood stream. In addition, both afferent and efferent neurons connect the teleost pineal organ to the diencephalon, although it lacks direct neural connections with the retina (Migaud et al., 2010). It is still unknown whether information about photoperiod is neurally transmitted to the brain. Unlike most teleosts, melatonin secretion in salmonids is directly regulated by photoperiod; its release is high during the scotophase and low during the photophase (Falcon et al., 2010).

Photoperiod affects muscular (Johnston et al., 2003), bone (Fjelldal et al., 2005), and gonadal (Taranger et al., 1998) growth plus development, behavior (Oppedal et al., 2001), appetite (Nordgarden et al., 2003a), lipid metabolism (Nordgarden et al., 2003b), and growth hormone $(\mathrm{GH})$, insulin-like growth factor (IGF)-I (Nordgarden et al., 2005), and sex steroid (Taranger et al., 1998) endocrinology in Atlantic salmon. Removal of the pineal gland abolishes the natural nocturnal rise in melatonin, affects the seasonal growth pattern (Mayer, 2000), and induces severe bone malformations (Fjelldal et al., 2004). Cortisol and GH act together during smoltification and seawater adaption in regulating gill $\mathrm{Na}^{+}, \mathrm{K}^{+}$-adenosine triphosphatase $\left(\mathrm{Na}^{+}, \mathrm{K}^{+}\right.$-ATPase $)$activity (McCormick, 2001). Atlantic salmon is an anadromous species exposed to marked seasonal changes in photoperiod and temperature in its habitat in the north Atlantic regions. Its preadaptation to a marine life prior to seawater migration during parr-smolt transformation involves dramatic changes in morphology, physiology, and behavior, and is induced mainly by increasing daylength during the spring (Folmar \& Dickhoff, 1980; Hoar, 1988; McCormick et al., 1998). As described in most seasonal mammals (Rousseau et al., 2003), annual rhythms are believed to be driven by an internal timing system, which is thought to be synchronized by the environment. Seasonal changes in the photoperiod, or daily amount of light, are the most predictable and critical environmental cues in the timing of annual functions, such as growth, immune response, and reproduction (Bromage et al., 2001; Endal et al., 2000). This suggests a connection between environmental inputs and complex biological functions. It has been known that the influence of the photoperiod on hormone release is regulated by the pituitary gland through the lightbrain-pituitary axis (LBP), which is important in smoltification (Ebbesson et al., 2007, 2008; Stefansson et al., 2007), and seasonal changes in plasma cortisol have been studied (Thorpe et al., 1987). However, the effects of the photoperiod on daily levels of plasma cortisol and lightsensitive clock genes, such as Per1 and Cry2, in the pineal gland are not clear in salmonids. 
Circadian rhythms have a period length of $\sim 24 \mathrm{~h}$ and regulate key biological processes (Duguay \& Cermakian, 2009; Koukkari \& Sothern, 2006). In mammals, the central clock is located in the suprachiasmatic nuclei (SCN) of the brain's hypothalamus (Antle \& Silver, 2005). The key components of circadian oscillators are based on negative and positive feedback loops. For the mammalian clock, the heterodimer protein complex CLOCK/BMAL1 is a transcription factor activating genes containing an E-box, among them PERIOD (PER), CRYPTOCHROME (CRY), which down-regulate CLOCK/BMAL1(Lowrey \& Takahashi, 2000). They constitute the core of the circadian clocks described as interlocking transcription/translation feedback loops similar to the one postulated in Drosophila and Neurospora (Benito et al., 2007; Dunlap, 1999). Through this mechanism, the functions and properties of various tissues and cell types can be properly maintained even during constant environmental conditions (Balsalobre, 2002; Ralph et al., 1990). Recent studies showed that local circadian clocks exist in the peripheral tissues and can be induced in vitro in some cultured cell lines and stem cells by various stimuli (Balsalobre et al., 1998; Huang et al., 2009; Mendez-Ferrer et al., 2008). Gene expression profiling in vivo in mouse liver and heart reveals that circadian gene regulation is present in $8 \%$ to $10 \%$ of the genes in each tissue (Storch et al., 2002). The increasing number of new clock components contributes to a better understanding of the complexity of the circadian mechanism (Dardente \& Cermakian, 2007). The peripheral clocks and post-translational modifications of clock proteins are known as important factors for the interaction of circadian system, physiology, and metabolism in mammals (Duguay \& Cermakian, 2009).

Among teleost, the zebrafish is the most studied species for the investigation of the effects of environmental stimuli, including light and temperature, on circadian clock mechanisms (Hirayama et al., 2005; Lahiri et al., 2005), although relatively few studies of the circadian system are available in salmonids. Recently, Davie et al. (2009) suggested that the clock gene system behind seasonal changes in daylength is conserved in Atlantic salmon, as described in vertebrates. The present study describes the daily expression of clock genes (Perl-like, Cry2, and Clock) in the pineal gland and brain and plasma levels of melatonin and cortisol in Atlantic salmon parr (LD) and smolts (LL). Smoltification was induced out-of-season by employing a commonly used photoperiod (Bjornsson et al., 2000).

\section{MATERIALS AND METHODS}

\section{Experimental Design}

On September 18th, 2007, 300 Atlantic salmon parr with a mean weight of $90 \mathrm{~g}$ were randomly allocated into three square, grey, covered 
fiberglass tanks $(1.5 \times 1.5 \times 0.5 \mathrm{~m})$ at the Institute of Marine Research in Matre $\left(60^{\circ} \mathrm{N}, 5^{\circ} \mathrm{E}\right.$, Western Norway). Triplicate groups of parr were subjected to standard 12-h light:12-h dark/day (LD) for 6 wks (wks 0 to 6), followed by $24 \mathrm{~h}$ of continuous light/day (LL) for 6 wks (wks 6 to 12). For illumination, two 18-W fluorescent daylight tubes were used to produce 960 lux under water in the center of the tank. The light was controlled by automatic timers, and was switched on at 08:05 h and switched off 20:05 h. The fish were reared in freshwater until December 14th. The temperature decreased from $12.0^{\circ} \mathrm{C}$ to $9.5^{\circ} \mathrm{C}$ during the period of $\mathrm{LD}$, and decreased from $9.5^{\circ} \mathrm{C}$ to $6.5^{\circ} \mathrm{C}$ during the period of LL. The fish were fed continuously (1.5\% of their biomass/day) from 08:05 to 20:05 h with a commercial diet (Nutra Olympic; Skretting, Averøy, Norway). The oxygen saturation of the outlet was kept $>80 \%$.

\section{Sampling of Atlantic Salmon Tissues for Expression Analysis}

During our study, two sampling periods (November 1st-2nd, 2007, and December 13th-14th, 2007) were used. Samples were taken every 4 th $\mathrm{h}$ for 24 consecutive hours under LD in wk 6 and under LL in wk 12. Each sampling was performed every 4 th $h$, with the first sampling starting at 12:00 $\mathrm{h}$ on day 1 and the last starting at 12:00 $\mathrm{h}$ on day 2 (day 1: 12:00, 16:00, 20:00, 24:00 $\mathrm{h}$ and day 2:04:00, 08:00, and 12:00 h). At each subsampling, three fish/tank were anesthetized with benzokain (40 $\mathrm{mg} \mathrm{L}^{-1}$ ) (Benzoak Vet; A.C.D., Braine-L'alleud, Belgium) and measured for fork length and body weight. The dark sampling of individual parr (LD) was performed under dim red light. The fish were then decapitated with a scalpel and their tissues dissected. The tissues (pineal gland and brain lacking pineal gland) were immediately frozen in liquid nitrogen. Since some of the pineal glands were lost either during tissue dissection or RNA purification, the number of harvested pineal glands varied between 6 and 9 per timepoint. During sampling, all fish were anesthetized at the same time, with one fish/tank sequentially measured and dissected to omit systemic errors caused by time-related differences in gene expression between tanks within the sampling points. The experimental protocol and procedures were performed in accordance with both international ethical standards (Portaluppi et al., 2008) and the National Animal Research Authority in Norway.

\section{Assays for Parr-Smolt Transformation}

The smolt status at transfer to seawater on December 14th was evaluated by gill $\mathrm{Na}^{+}, \mathrm{K}^{+}$-ATPase activity (McCormick et al., 1987), CF (condition factor) (Farmer et al., 1978), and qualitative evaluation of skin silvering. The $\mathrm{CF}$ was calculated according to the following formula: 
$\mathrm{CF}=\left(W L^{-3}\right) \times 100$, where $W$ is the live body weight $(\mathrm{g})$ and $L$ is the fork length $(\mathrm{cm})$. The gill $\mathrm{Na}^{+}, \mathrm{K}^{+}$-ATPase activity was measured in 12 individuals, $4 /$ tank.

\section{Levels of Plasma Melatonin and Cortisol}

Plasma melatonin levels were determined by radioimmunoassay (RIA) kit without extraction, in which the plasma sample was incubated with assay buffer, ${ }^{125}$ I-melatonin, and rabbit anti-melatonin antiserum, as described in the manufacturer's instructions (IBL, Hamburg, Germany). The intra- and interassay coefficient of variation (CV) values were 3.0-11.4 and 6.4-19.3, respectively. The cortisol concentration was measured by RIA kit (DiaSorin, Minnesota, USA) with intra- and interassay $\mathrm{CV}$ values of $7.1 \%$ and $9.2 \%$, respectively. The plasma samples of 10 $\mu \mathrm{L}$ were directly added to anti-cortisol-coated tubes along with $1 \mathrm{~mL}$ of radiolabeled tracer buffer. The tubes were incubated for $1 \mathrm{~h}$ at $37^{\circ} \mathrm{C}$ in a water bath. The tubes were decanted thoroughly, and the radioactivity was measured using ${ }^{125}$ I-gamma counter. The cortisol levels were all within the detection range of the kit $(0-600 \mathrm{ng} / \mathrm{mL})$. The assays used had been previously validated for use in Atlantic salmon in our Institute, and the assay procedures were performed according to the manufacturer's instructions.

\section{Isolation of RNA and Quantitative Reverse Transcriptase-Polymerase Chain Reaction (qRT-PCR) Analysis}

RNA isolation and DNase treatment of the tissue samples were performed using the standard RNA extraction method (Invitrogen, Paisley, UK) and DNA-free DNase following the manufacturer's protocol. The total RNA, $500 \mathrm{ng}$ of each sample, was reverse transcribed using TaqMan RT reagents (ABI, Foster City, CA, USA). A standard curve was obtained from a two-fold serial dilution of total RNA from the control fish at six concentrations, from 1000 to $31.25 \mathrm{ng}$. The annotated expressed sequence tag (EST) sequences of Cry2 and Clock were obtained from the Salmon Genome Project (SGP) database: www.salmongenome.no, as described by Davie et al. (2009). In order to identify salmon Per ortholog from the EST sequence, PCR primers, 5'-CCCAGTGACCTACTGG ACCTG-3' and 5'-TGGTGCTCTCTGGTAAGG-3', were designed to amplify a partial cDNA fragment $(576 \mathrm{bp})$ from Atlantic salmon liver mRNA by PCR reaction. We refer to this gene as Perl-like gene. The amplified PCR products of all three clock genes were sequenced to ensure the correct mRNA sequences for quantification. The primers shown in Table 1 were used for SYBR Green assays (Roche Diagnostics, Germany) in a total volume of $20 \mu \mathrm{L}$ containing $1 \mu \mathrm{L}$ cDNA, $10 \mu \mathrm{L}$ SYBR 
TABLE 1 Primer sequences used in qPCR of the reference and clock genes studied

\begin{tabular}{llll}
\hline Gene & $\begin{array}{c}\text { Accession } \\
\text { number }\end{array}$ & \multicolumn{1}{c}{ Forward primer } & \multicolumn{1}{c}{ Reverse primer } \\
\hline Per1-like & DW576689 & $5^{\prime}$-CTGTCTCCTTGGGCACTGTGT-3' & $5^{\prime}$-GAGTCGATGCTGCCAAAGTACTT-3' \\
Clock & CA038738 & $5^{\prime}$-GTTAGACGGCTTCTTCCTAGCAAT-3' & $5^{\prime}$-CCACCAGGTCAGAAGGAAGATG-3' \\
Cry2 & DY730105 & $5^{\prime}$-CCACAACATGGCAGGTGAATT-3' & $5^{\prime}$-CAGACATCCAAAGCGGAGGTA-3' \\
ß-Actin & BG933897 & $5^{\prime}$-CCAAAGCCAACAGGGAGAAG-3' & $5^{\prime}$-AGGGACAACACTGCCTGGAT-3' \\
EF1AB & AF321836 & $5^{\prime}$-TGCCCCTCCAGGATGTCTAC-3' & $5^{\prime}$-CACGGCCCACAGGTACTG-3' \\
\hline
\end{tabular}

Green master, $0.2 \mu \mathrm{L}(50 \mu \mathrm{M})$ of each primer, and $8.6 \mu \mathrm{L} \mathrm{H}_{2} \mathrm{O}$. Reactions were run on a Roche LightCycler 480 (Roche Diagnostics) with 96 wells. The cycling conditions were composed of preincubation at $95^{\circ} \mathrm{C}$ for $5 \mathrm{~min}$, followed by 45 cycles of amplification. Each cycle included $10 \mathrm{~s}$ of denaturation at $95^{\circ} \mathrm{C}, 20 \mathrm{~s}$ of primer annealing at $60^{\circ} \mathrm{C}$, and $30 \mathrm{~s}$ of extension/synthesis at $72^{\circ} \mathrm{C}$. The gene expression stability (M) was calculated with geNorm, and the two reference genes ( $\beta$-actin and EF1AB) showed a low $\mathrm{M}$ value $(<0.5)$. The geNorm tool was used to determine a normalizing factor from the two reference genes ( $\beta$-actin and EF1AB) to parr (LD) and smolt (LL) and used to calculate the normalized expression for the target genes (Vandesompele et al., 2002).

\section{Statistical Analysis}

Significant differences between the timepoint means of each clock gene and plasma levels of melatonin and cortisol were evaluated by oneway analysis of variance (ANOVA) (Statistica, Statsoft, Tulsa, USA). If the ANOVA test showed a statistical significance $(p<.05)$, a Newman-Keuls test was applied to determine all pairwise comparisons. Since all that ANOVA can test for is whether one or more timepoint values differ from the others, ANOVA cannot assess rhythmicity. The cosinor method was used to analyze circadian rhythms using normalized data for each variable in three separate analyses (the average of the three fish of each tank, $n=3 /$ timepoint), and in one cosinor test using the means for each timepoint (means of total fish from all the tanks). The analyses validated significant 24.0 -h periodicity by the zero-amplitude test of the cosinor procedure. The analysis was performed by cosinor periodogram (www .circadian.org/softwar.html). The rhythm characteristics estimated by this method include the mesor (middle value of the fitted cosine, representing a rhythm-adjusted mean), amplitude (half the difference between the minimum and maximum of the fitted cosine function), and acrophase (the time of the peak value of a rhythm, expressed in $h$ and $\min )$. 


\section{Phylogenetic Tree Analysis}

The deduced amino acid sequence and the alignments were analyzed by the BLAST search program (National Center for Biotechnology International $[\mathrm{NCBI}]$, Bethesda, MD, USA). Multiple alignments were constructed by ClustalW2 (www.ebi.ac.uk/Tools/clustalw2), and the phylogenetic tree of C-termimal domain of PER protein sequences was constructed using a neighbor-joining method with the phylogram.

\section{RESULTS}

\section{Somatic Growth, Smolt Status, and Plasma Levels of Cortisol}

The fork length, body weight, and condition factor of the parr (wk 6) and the smolts (wk 12) are shown Table 2. Under continuous light, LL (wks 6 to 12), the fish developed the skin silvering typical of smolts and showed a significant decrease in CF. The $\mathrm{Na}^{+}, \mathrm{K}^{+}$-ATPase activity in wk 12 demonstrated a normal distribution around the mean value of $9.2 \mathrm{mmol} \mathrm{ADP} / \mathrm{mg}$ protein $/ \mathrm{h}$ (minimum value 6.9 , maximum value 12.5). Under LD conditions, plasma melatonin levels were typically low during the light phase and gradually increased during the dark phase; in contrast, cortisol levels peaked during light phase and declined during dark phase, whereas in LL there were no significant rhythmic levels in smolts (Figure 1, Table 3).

\section{Variations of Daily Clock Gene Expression in Parr (LD) and Smolts (LL)}

In parr that had been under LD treatment for 6 wks, Per1-like and Cry2 displayed significant rhythms in the pineal gland and brain (Figure 2, Table 3), although their acrophases and amplitudes differed from one another. The peak time of Perl-like was in the middle of the dark phase in the pineal gland $(02: 28 \pm 0.4 \mathrm{~h})$, whereas it was late in the light phase in the brain $(19: 11 \pm 0.54 \mathrm{~h}$ ) (Table 3). In contrast, the expression of $\mathrm{Cry} 2$ peaked during the dark phase in both tissues, with an $\sim 3$-h phase-shift in the brain $(02: 08 \pm 0.4 \mathrm{~h})$ compared to the pineal

TABLE 2 Body weight $(\mathrm{g})$, fork length $(\mathrm{cm})$, and condition factor $(\mathrm{CF})$ (mean $\pm \mathrm{SD})$ of the fish during the experimental period $(n=63 /$ group; $21 /$ tank $)$

\begin{tabular}{lcc}
\hline Parameter & Parr (LD, wk 6) & Smolts (LL, wk 12) \\
\hline Length & $22.9 \pm 2.2$ & $25.2 \pm 2.0$ \\
Weight & $159.8 \pm 41.2$ & $196.6 \pm 52.6$ \\
CF & $1.31 \pm 0.08$ & $1.21 \pm 0.08$ \\
\hline
\end{tabular}



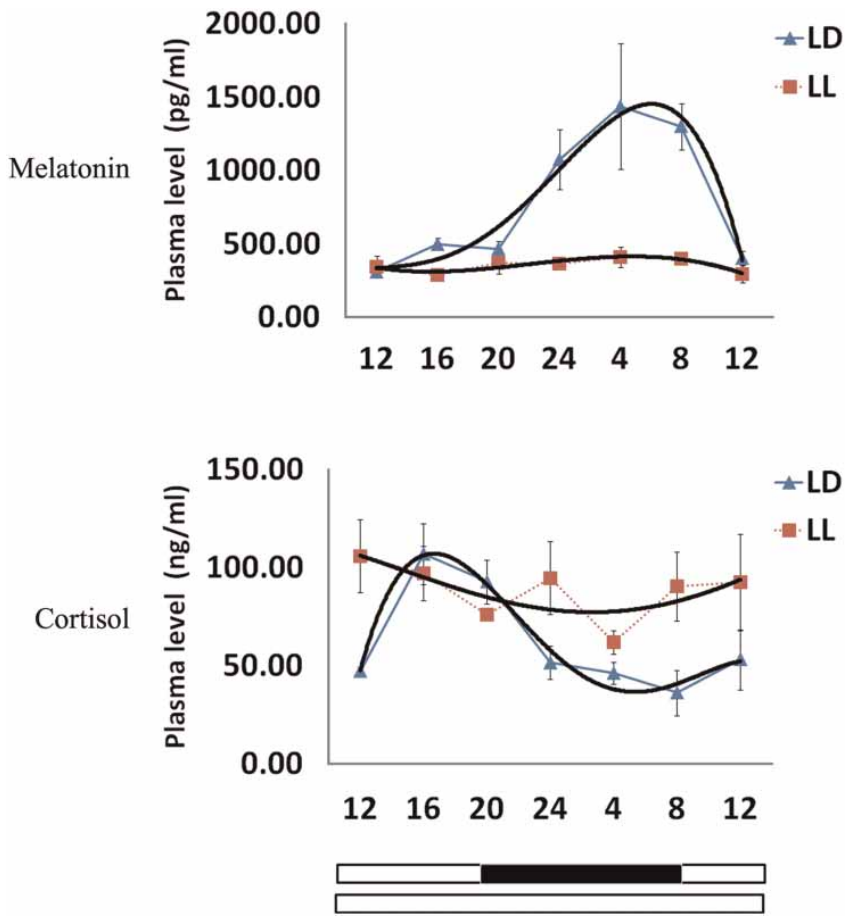

FIGURE 1 Daily Plasma levels of melatonin and cortisol in Atlantic salmon parr and smolt. The plasma levels of cortisol were measured from parr reared under a 12-h light:12-h dark cycle and smolts reared under $24 \mathrm{~h}$ of continuous light (LL) for $6 \mathrm{wks}$. Circadian rhythms were determined by three separate cosinor analyses, and the statistical significance is denoted in the text. Each value is the mean \pm SEM ( $\mathrm{n}=3$, 3 fish/tank). LD, 12-h light:12-h dark; LL, continuous light.

TABLE 3 Summary of clock gene expression and plasma melatonin and cortisol from cosinor analysis in parr under LD

\begin{tabular}{llcccc}
\hline Variable & Tissue & Mesor \pm SD & Amplitude \pm SD & Acrophase & Cosinor $p$ \\
\hline Per1-like & Brain & $0.57 \pm 0.02$ & $0.34 \pm 0.05$ & $19: 11 \pm 0.54$ & $<.05$ \\
& Pineal & $0.62 \pm 0.06$ & $0.44 \pm 0.11$ & $02: 28 \pm 0.40$ & $<.01$ \\
Cry2 & Brain & $0.84 \pm 0.03$ & $0.27 \pm 0.05$ & $02: 08 \pm 1.89$ & $<.05$ \\
& Pineal & $0.69 \pm 0.06$ & $0.37 \pm 0.03$ & $22: 32 \pm 1.12$ & $<.01$ \\
Clock & Pineal & $0.88 \pm 0.08$ & $0.36 \pm 0.15$ & $19: 30 \pm 0.51$ & $<.05$ \\
Melatonin & Plasma & $896.5 \pm 102.5$ & $764.5 \pm 157.2$ & $03: 26 \pm 0.09$ & $<.05$ \\
Cortisol & Plasma & $67.0 \pm 7.35$ & $40.95 \pm 7.96$ & $18: 31 \pm 0.01$ & $<.05$ \\
\hline
\end{tabular}

gland (22:32 $\pm 1.12 \mathrm{~h}$ ) (Table 3$)$. There were no overall 24-h rhythms for Clock in the brain, but there was a significant rhythm in the pineal gland, which peaked late in the light phase $(19: 30 \pm 0.5 \mathrm{~h})$ (Figure 2, Table 3). This reflects an $\sim 7$-h time difference between Perl-like and Clock peak expression in the pineal gland. Of the studied genes and organs, the 

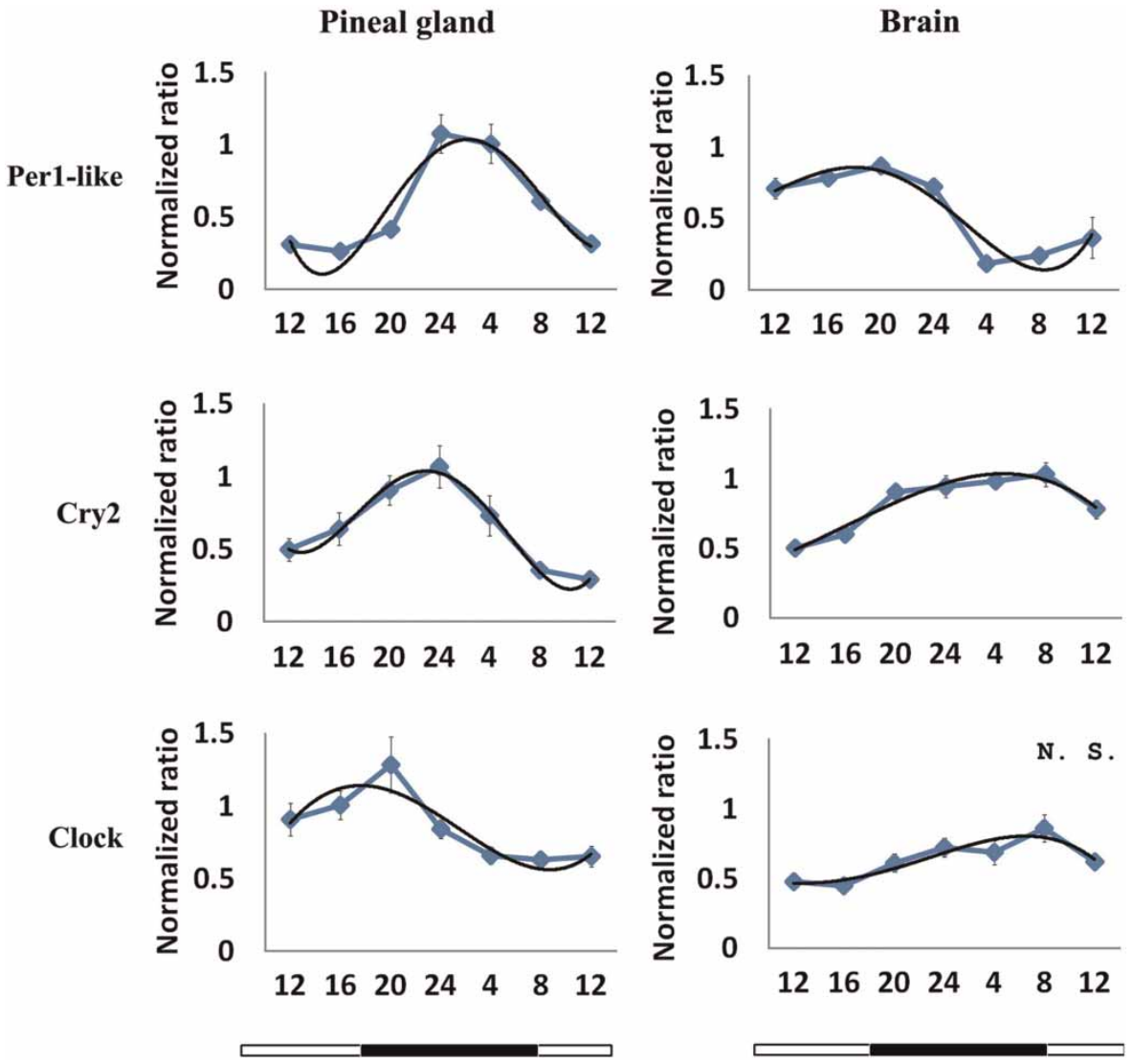

FIGURE 2 Daily expression of clock genes in parr of Atlantic salmon. The expression of clock mRNAs in the pineal gland and brain harvested from parr (LD) was normalized by two endogenous control genes, $\beta$-actin and EF1AB. Circadian rhythms were determined by three separate cosinor analyses, and the statistical significance is shown in Table 3 . Each value is the mean \pm SEM ( $n=3,3$ fish/ tank), with the exception of pineal glands ( $\mathrm{n}=3$, 2-3 fish/tank). LD, 12-h light:12-h dark; LL, continuous light; N.S., not significant.

diurnal expression of Per1-like and Cry2 in the pineal gland yielded the most pronounced oscillation $(p<.01$; Table 3$)$.

In smolts that developed their characteristics after $6 \mathrm{wks}$ in LL, no significant rhythms for any of the measured clock genes could be observed in the pineal gland and brain (Figure 3).

\section{DISCUSSION}

In the present experiments, we found significant daily variations in the measured clock genes in the pineal gland and brain of parr under LD and the plasma levels of melatonin and cortisol, whereas there were 

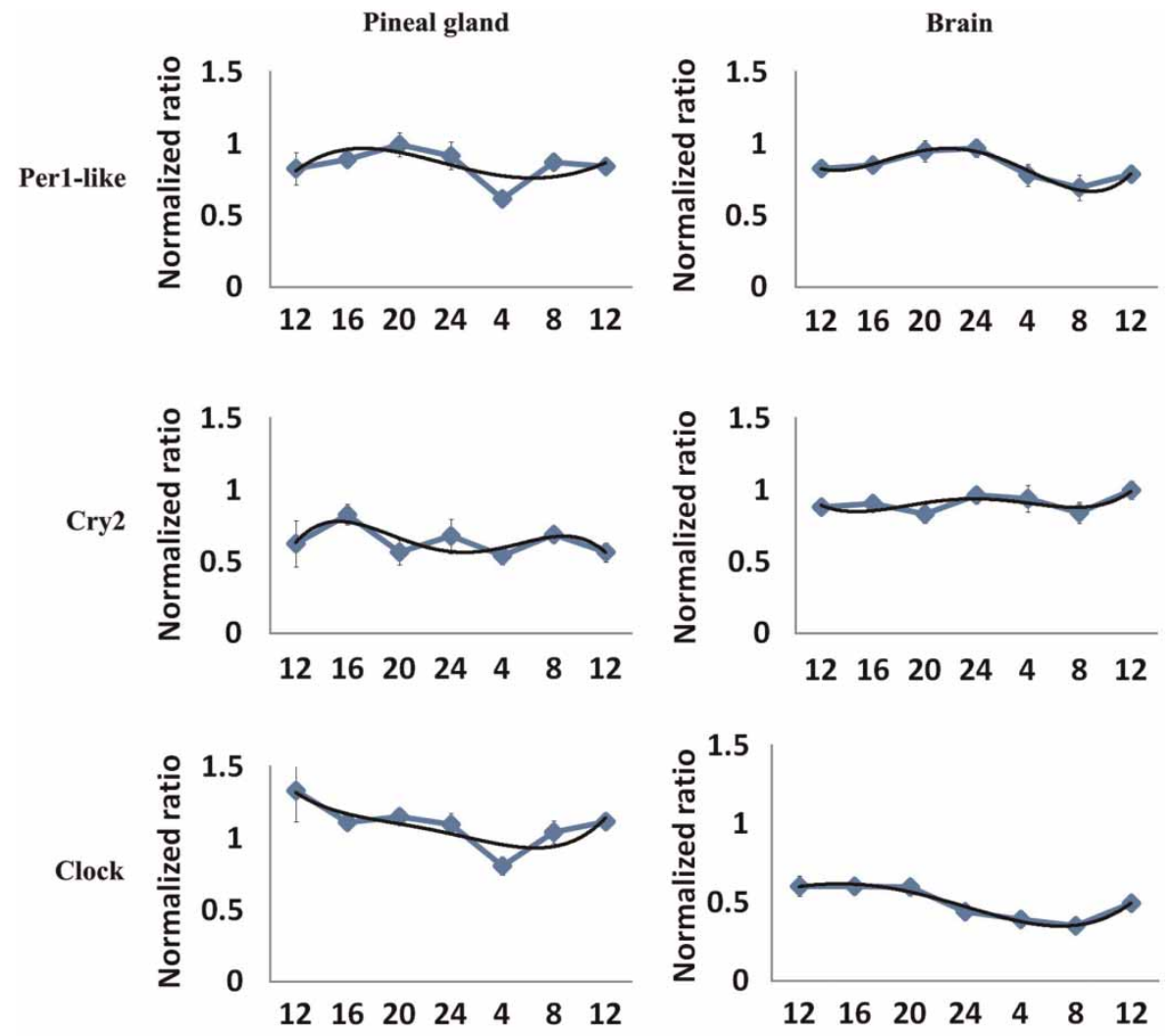

FIGURE 3 Daily expression of clock genes in smolts of Atlantic salmon. The mRNA expression of clock genes of the pineal gland and brain harvested from smolts under LL was normalized by two endogenous control genes, $\beta$-actin and $E F 1 A B$. Each value is the mean $\pm \operatorname{SEM}(\mathrm{n}=3,3 \mathrm{fish} / \operatorname{tank})$, with the exception of pineal glands ( $\mathrm{n}=3$, 2-3 fish/tank). LD, 12-h light:12-h dark; LL, continuous light; LL, continuous light.

no variations in smolts under LL. In the study, we first observed daily changes of plasma melatonin levels under LD, whose levels were elevated in the dark phase and suppressed in the light phase (Iigo et al., 1997; Randall et al., 1995), whereas the plasma levels of cortisol peaked during the second half of the light phase in parr (LD). The level of cortisol in parr displayed significant daily rhythms, and smolts showed higher basal levels than parr. Thus, it is not likely that the cortisol levels were a result of stress state. The current level of cortisol in parr is in the upper range of the basal level of cortisol of $\sim 3-82 \mathrm{ng} / \mathrm{mL}$ (Barton \& Iwama 1991; Eliason et al., 2007; Espelid et al., 1996; Gamperl et al., 1994; Wiik et al., 1989). We suggest that the higher basal level may be related to sampling intensity, assay specificity, capture procedure, and other internal and external factors, as described by Pottinger et al. (2000). In contrast, daily 
rhythms of plasma cortisol levels were not seen in parr under a winter photoperiod (Thorpe et al., 1987), whereas the nocturnal increase in cortisol levels was reported in smolts under a spring photoperiod (Ebbesson et al., 2008). The acrophase of the cortisol rhythm can vary depending on the species studied and seasonal daylength (Ebbesson et al., 2008; Li \& Takei, 2003; Pavlidis et al., 1999; Pickering \& Pottinger, 1983). Continuous light exposure affects the growth rate, timing of smoltification, and reproduction of Atlantic salmon (Krakenes et al., 1991; Saunders \& Henderson, 1988; Stefansson et al., 1991), and abolishes the natural nocturnal rise in plasma melatonin. However, the connection between the effect of continuous light on melatonin and cortisol rhythms, or the link between melatonin and cortisol is not clear in Atlantic salmon.

In parr, all the genes showed significant temporal variation in the pineal gland, whereas only Per1-like and Cry2 displayed significant variation in the brain. For that reason, the temporal variation of clock gene expression appears to be organ specific with regard to phase, amplitude, and rhythmicity. This observation has been reported in zebrafish, in which the variability of the clock gene expression present in the tissues suggests that there are more clock genes present in zebrafish than in mammals (Cahill, 2002). In the pineal gland of parr, it is interesting to note in the current study that light up-regulated Clock displayed a distinct rhythmic pattern that was antiphasic to the dark up-regulated Per1-like and Cry2. A study by Simonneaux et al. (2004) revealed that the nocturnal expression of Per 1 and Cry 2 in the rat pineal gland is regulated by the clock-driven changes in norepinephrine, in much the same manner as the melatonin rhythm-generating enzyme arylalkylamine $N$-acetyltransferase (AANAT). Similarly, the pineal AANAT mRNA expression is regulated by pineal circadian oscillators in many teleost species, though not in rainbow trout (Begay et al., 1998). Further, in vitro experiments reported by Iigo et al. (2007) revealed no endogenous rhythm in the pineal melatonin secretion, and salmonids may evolve a decentralized system in which the pineal gland responds directly to light, independently of the eyes (Migaud et al., 2007). A recent report by Davie et al. (2009) has proposed that a daylength-dependent clock gene system is active in the salmon brain. Together with the data presented here, Atlantic salmon express clock genes in the pineal gland and brain, although a functional circadian clock has yet to be demonstrated. It seems that salmonids exhibit notable daily and annual rhythms, which may be a passive type of response to the variations in photoperiod and temperature, unlike other teleost driven by internal clocks (Falcon et al., 2010). Thus, the role of the clock genes in the regulation of somatic growth, smoltification, and sexual maturation, and whether a master clock exists in a SCN-like structure in the brain, remains to be elucidated. 
In the photosensitive pineal gland, the peak in salmon Perl-like expression seems to occur after the light-dark transition under LD. In zebrafish, rhythmic expression of Perla (previously referred to Perl), Per2, and Per3 with different timing of their maximal expression was reported in an in vitro embryo system (Pando et al., 2001). Perla and Per3 were activated before the onset of light, whereas Per2 seems to be strictly light-induced in the cell line (Pando et al., 2001; Ziv \& Gothilf, 2006). Vallone et al. ( 2004) discovered a new gene, Per4, now referred to as Perlb under the new nomenclature proposed by Wang (2008), whose rhythmicity in larvae and in a zebrafish cell line was remarkably repressed by light, similar to those of Perla and Per3 under LD conditions. A recent analysis of goldfish clock genes also showed the opposite phase relationship of Per1 and Per2 in the retina under LD, in which Per1 peaked at midnight and Per2 at midday (Velarde et al., 2009). In golden rabbitfish, the expression pattern of Perlb increased in the dark phase with a peak at dawn in the whole brain and cultured pineal gland (Park et al., 2007), which was similar to that of zebrafish Perla, Per1b, and Per3. These current findings support an expression pattern of Per1-like in the pineal gland that peaked in the dark phase. By using the NCBI BLAST program, the putative amino acid sequence derived from a cDNA fragment of Atlantic salmon Perl-like showed greatest homology with golden rabbitfish PER1b (79\% identity), compared to $64 \%$ identity of zebrafish PERla. This partial protein sequence is at the carboxyl terminus of PER1, including a carboxyl-terminal serine/threonine-glycine (SG) repeat region (Park et al., 2007). In order to compare similarity of this partial PER1-like protein between Atlantic salmon and other species, the phylogenetic tree showed that Atlantic salmon PER1-like protein is more similar to teleost PER1b than to the other PER proteins (Figure 4A). Identification of a carboxyl domain of PER1 and PER2 for the interaction with CRY has been reported in mouse (Eide et al., 2002), and a conserved Cry-binding domain was predicted in teleost PER proteins (Figure 4B). Several single-amino acid substitutions within conserved residues not only affect its interaction with CRY1 but also the translocation of PER (Tomita et al., 2010). Collection of these evidences suggests that a member of the PER family was confirmed in Atlantic salmon that has a strong homology to the known PERlb.

In the present study, the pineal Cry2 peaked in the early night and brain Cry 2 at midnight under LD, similar to the nocturnal expression of goldfish retina Cry2 (Velarde et al., 2009) and expression of zebrafish eye Cry $2 a$ and Cry2b at dusk (Kobayashi et al., 2000). As described in Atlantic salmon, the brain Cry2 peaked in the early night in short-day photoperiod (SD) (6L:18D) and at midnight in long-day (LD) photoperiod (18L:6D) (Davie et al., 2009). When we compare pineal and brain clock mRNAs, the acrophases differed among the two tissues for both Per1-like 
A

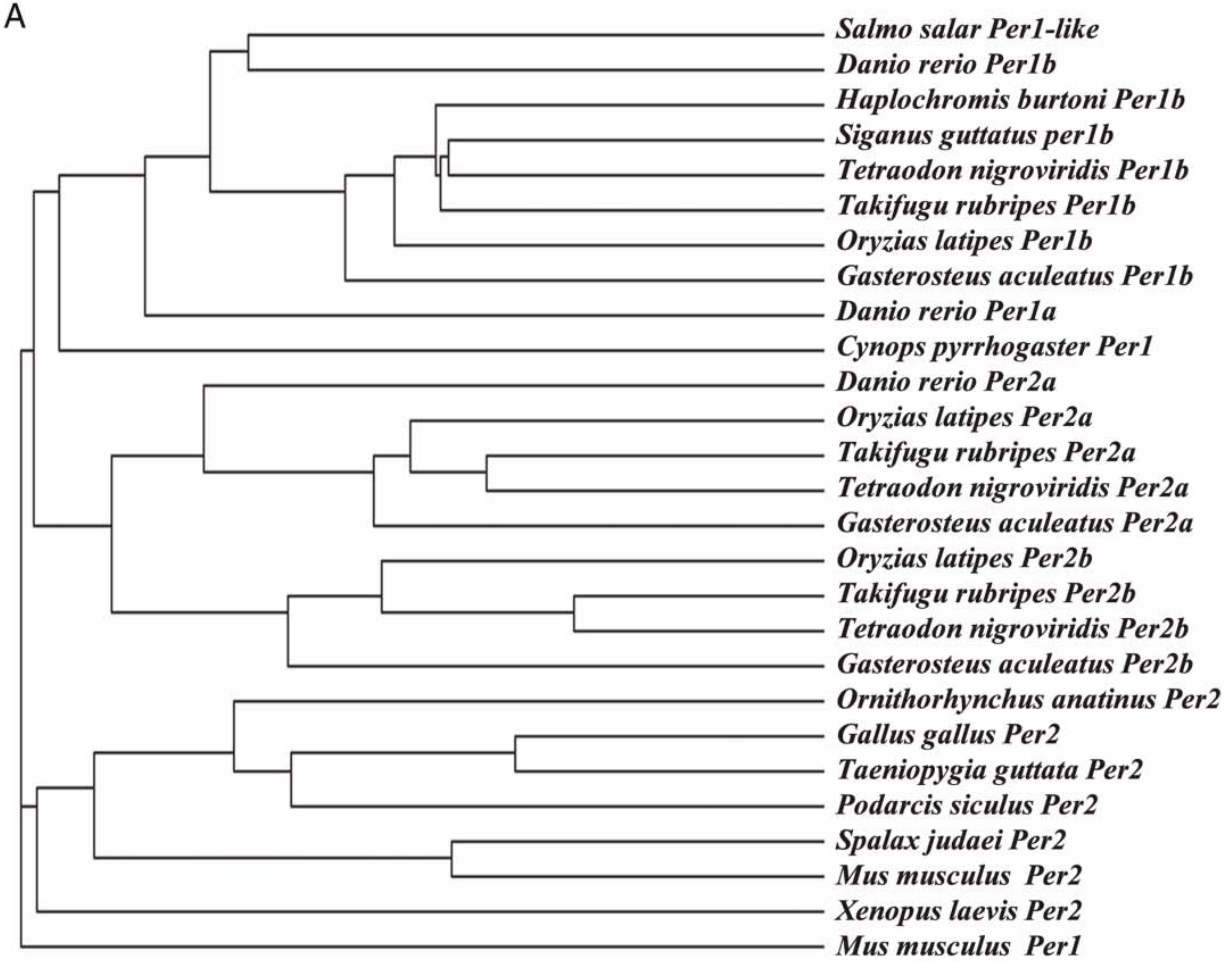

B

Salmo salar Per1-like
Danio rerio Per1b
Danio rerio Perla
Mus musculus Per1
Danio rerio Per2b
Mus musculus Per2
Danio rerio Per3
Mus musculus Per3

RQDREALRAMHKHQPRFTEDQKRELSQVHPWIRTGRLP KEDRAALRAMQKHQPRFTEEQKSELSQVHPWIRTGRLP KEDRDALKAAQKHQPHFTEEQKKELTQVHPWIQTGCLP KQDRERLRAMQKQQPRFSEDQRRELGAVHSWVRKGQLP REDREKLRQMQKSQPRFTDEQKRELADVHPWMRRGGLP KEDQEKLKLLQRSQPRFTEGQRRELREVHPWVHTGGLP QEDREKLILMQPMQPWFTSDQKKELAEVHPWIQQNTVP KQDLEKLQSMEQQQPLFSPAQREELAKVRSWIHSHTAP

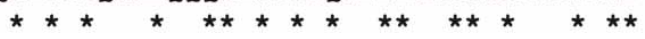

FIGURE 4 Alignments and phylogenetic analysis of Atlantic salmon partial PER1-like protein and PER proteins of other species. (A) The tree was generated using the ClustalW program and visualized with TreeView with 1000 bootstrapping iterations. The accession numbers of each PER proteins are indicated as follows: Salmo salar Per1-like (DW576689); Danio rerio Per1b (BC163718.1); Haplochromis burtoni Per1b (ABI95427); Siganus guttatus per1b (DQ198087.1); Tetraodon nigroviridis Per1b (ENSTNIP00000010000); Takifugu rubripes Per1b (ENSTRUP00000036869); Oryzias latipes Per1b (NP_001129992); Gasterosteus aculeatus (ENSGACG00000019308); Danio rerio Per1a (AI63543); Cynops pyrrhogaster Per1(BAC98490); Danio rerio Per2a (AAI63549); Oryzias latipes Per2a (ENSORLG00000016612); Takifugu rubripes Per2a (SINFRUG00000138842); Tetraodon nigroviridis Per2a (GSTENG00028368001); Gasterosteus aculeatus Per2a (ENSGACG00000013485); Oryzias latipes Per2b (ENSORLG00000015456); Takifugu rubripes Per2b (SINFRUG00000130362); Tetraodon nigroviridis Per2b (GSTENG00026769001); Gasterosteus aculeatus Per2b (ENSGACG00000005662); Ornithorhynchus anatinus Per2 (XP_001506324); Gallus gallus Per2 (NP_989593); Taeniopygia guttata Per2 (XP_002188433); Podarcis siculus Per2 (CAI43981); Spalax judaei Per2 (AJ345060); Mus musculus Per2 (NP_035196); Xenopus laevis Per2 (NP_001081099); Mus musculus Per1 (NP_001152839). (B) Multiple alignment of conserved Cry-binding domain for PER proteins from Atlantic salmon, zebrafish, and mouse. All sequences were obtained from GenBank entries of CRY-binding domain of mouse PER2. Conserved residues critical for the function are highlighted by asterisk. The accession numbers of PER3 are Danio rerio (NP_571659) and Mus musculus (NP_035197). 
and Cry2. Since the brain samples compromised whole brains without pineal glands and were not microdissected according to brain area, it may have biased the results due to variations existing in the different brain areas. Concerning Clock expression in salmon organs, the pineal Clock exhibited its maximum at the end of light phase, whereas it occurred at the end of dark phase in the brain, although it did not show significant 24-h rhythmicity by cosinor analysis. Similarly, it has been reported that Clock peaks in the brain during the mid-dark phase in salmon parr in SD (Davie et al., 2009). Thus, the peak time of Clock expression may differ between organs and depend on photoperiods. The discrepancy in acrophases of Atlantic salmon clock mRNAs between the pineal gland and brain may be due to variations existing in the different brain areas, since the brain samples compromised whole brains lacking pineal glands. Melatonin has been known to convey information about daylength light to peripheral organs, and the discrepancy in acrophases of Atlantic salmon clock mRNAs was observed in the various organs, suggesting that a set of genes that peak during the day or later at night may be regulated by pathways that are indirectly activated by melatonin or perhaps by a "master clock" located within a SCN-like structure in the brain.

The expression of Per1-like, Cry2, and Clock was not rhythmic in smolt in LL. In contrast, Per1-like and Cry2 expression peaked at midnight in the pineal gland from parr in LD. Such elevation of both genes at midnight disappeared in smolts under LL, suggesting that the expression of Per1-like and Cry2 are repressed in smolt kept in LL. It is possible that clock proteins are more stable in LL than in LD, or the repression mechanism does not work well under LL. In out-of-season smolt production, 6 wks with continuous light mimics a spring period and induces smoltification. However, during "in season" smoltification, parr-smolt transformation is induced by an increased daylength during the spring. The former involves a lack of daily variations in both plasma melatonin and cortisol and tissue clock gene expression, whereas the latter involves the presence of a daily variation in plasma melatonin at peak smoltification (seawater transfer). Our results from smolts under LL do not support the hypothesis proposed by Taylor et al. (2005) that growth is maintained by a possible endogenous rhythm and which is known to free-run in the absence of a changing photoperiod under LL. Since the pineal gland of salmonids does not possess an endogenous clock responding only to light, it may explain why clock genes do not fluctuate daily when the fish are reared under LL conditions. Although it is unknown if the clock gene RNA levels can be compared between parr and smolts with different photoperiod and temperature and it is not clear from the present data if the change in clock gene expression during smoltification was due to LL exposure or to developmental change, we have unpublished data on 
clock gene expression in smolts under LL and 18:6 LD that indicate the lack of daily variation in clock gene expression in smolts under LL is more related to light than developmental stages. Thus, at present, a rationale connecting the photoperiod and plasma levels of melatonin and cortisol to the regulation of tissue-specific clock genes, and in turn to the regulation of parr-smolt transformation, is difficult to postulate. The use of a natural water source in the present study, with a decreasing temperature $\left(\sim 0.06^{\circ} \mathrm{C} /\right.$ day $)$ during the experimental period, may have a limited influence on the results. It has been known that seasonal changes in daylength and temperature have an effect on the amplitude and duration of the levels of nocturnal melatonin. Nevertheless, all fish underwent a successful parr-smolt transformation.

The current findings show that variations of clock gene expression exist in the pineal gland and brain of parr under LD but not in smolts under LL, showing that this is an interesting subject for further research on the molecular mechanism that couples information about daylength to endocrine changes. However, in our studied model, it is impossible to distinguish if the observed changes in clock gene expression when the fish change from parr to smolts is due to LL or developmental change. Thus, it is necessary to investigate whether the clock gene system is entrained in a daylength-dependent manner during smoltification. It still needs to be determined whether the pineal clock genes have a link to the gene expression of the melatonin-synthesizing enzyme and/or melatonin release, how the circadian clocks oscillate in different areas of the salmonid brain, and whether the present results reflect changes in the clock gene system related to smoltification or photoperiod.

\section{ACKNOWLEDGMENTS}

This work was supported by the NIFES Internal Project. We wish to thank Eva Mykkeltvedt, Jacob Wessels, Leikny Fjeldstad, and Hui-shan Tung for their excellent analytical work at NIFES. We also want to thank Roberto Refinetti of the University of South Carolina, Circadian Rhythm Laboratory, for his discussion of cosinor analyses, Ole Didrik Lærum of the University of Bergen for his critical reading of the manuscript.

Declaration of Interest: The authors report no conflicts of interest. The authors alone are responsible for the content and writing of the paper.

\section{REFERENCES}

Antle MC, Silver R. (2005). Orchestrating time: arrangements of the brain circadian clock. Trends Neurosci. 28:145-151.

Balsalobre A. (2002). Clock genes in mammalian peripheral tissues. Cell Tissue Res. 309:193-199. 
Balsalobre A, Damiola F, Schibler U. (1998). A serum shock induces circadian gene expression in mammalian tissue culture cells. Cell 93:929-937.

Barton BA, Iwama GK. (1991) Physiological changes in fish from stress in aquaculture with emphasis on the response and effects of corticosteroids. Annu. Rev. Fish Dis. 1:3-26.

Begay V, Falcon J, Cahill GM, Klein DC, Coon SL. (1998). Transcripts encoding two melatonin synthesis enzymes in the teleost pineal organ: circadian regulation in pike and zebrafish, but not in trout. Endocrinology 139:905-912.

Benito J, Zheng H, Ng FS, Hardin PE. (2007). Transcriptional feedback loop regulation, function, and ontogeny in Drosophila. Cold Spring Harb. Symp. Quant. Biol. 72:437-444.

Bjornsson BT, Hemre GI, Bjornevik M, Hansen T. (2000). Photoperiod regulation of plasma growth hormone levels during induced smoltification of underyearling Atlantic salmon. Gen. Comp. Endocrinol. 119:17-25.

Bromage N, Porter M, Randall C. (2001). The environmental regulation of maturation in farmed finfish with special reference to the role of photoperiod and melatonin. Aquaculture 197:63-98.

Cahill GM. (2002). Clock mechanisms in zebrafish. Cell Tissue Res. 309:27-34.

Dardente H, Cermakian N. (2007). Molecular circadian rhythms in central and peripheral clocks in mammals. Chronobiol. Int. 24:195-213.

Davie A, Minghetti M, Migaud H. (2009). Seasonal variations in clock-gene expression in Atlantic salmon (Salmo salar). Chronobiol. Int. 26:379-95.

Duguay D, Cermakian N. (2009). The crosstalk between physiology and circadian clock proteins. Chronobiol. Int. 26:1479-513.

Dunlap JC. (1999). Molecular bases for circadian clocks. Cell 96:271-90.

Ebbesson LOE, Ebbesson SOE, Nilsen TO, Stefansson SO, Holmqvist B. (2007). Exposure to continuous light disrupts retinal innervation of the preoptic nucleus during parr-smolt transformation in Atlantic salmon. Aquaculture 273:345-349.

Ebbesson LO, Bjornsson BT, Ekstrom P, Stefansson SO. (2008). Daily endocrine profiles in parr and smolt Atlantic salmon. Comp. Biochem. Physiol. A Mol. Integr. Physiol. 151:698-704.

Eide EJ, Vielhaber EL, Hinz WA, Virshup DM. (2002). The circadian regulatory proteins BMAL1 and cryptochromes are substrates of casein kinase Iepsilon. J. Biol. Chem. 277:17248-17254.

Ekstrom P, Meissl H. (1997). The pineal organ of teleost fishes. Rev. Fish Biol. Fish 48:1011-1013.

Eliason EJ, Kiessling A, Karlsson A, Djordjevic B, Farrell AP. (2007). Validation of the hepatic portal vein cannulation techniques using Atlantic salmon Salmo salar L. J. Fish Biol. 71:290-297.

Endal HP, Taranger GL, Stefansson SO, Hansen T. (2000). Effects of continuous additional light on growth and sexual maturity in Atlantic salmon, Salmo salar, reared in sea cages. Aquaculture 191:337-349.

Espelid S, Lokken GB, Steiro K, Bøgwald J. (1996). Effects of cortisol and stress on the immune system in Atlantic salmon (Salmo salar). Fish Shellfish Immunol. 6:95-110.

Falcon J, Migaud H, Munoz-Cueto JA, Carrillo M. (2010). Current knowledge on the melatonin system in teleost fish. Gen. Comp. Endocrinol. 165:469-482.

Farmer GJ, Ritter JA, Ashfield D. (1978). Seawater adaptation and parr-smolt transformation of juvenile Atlantic salmon, Salmo-Salar. J. Fish. Res. Board Can. 35:93-100.

Fjelldal PG, Grotmol S, Kryvi H, Gjerdet NR, Taranger GL, Hansen T, Porter MJ, Totland GK. (2004). Pinealectomy induces malformation of the spine and reduces the mechanical strength of the vertebrae in Atlantic salmon, Salmo salar. J. Pineal Res. 36:132-139.

Fjelldal PG, Nordgarden U, Berg A, Grotmol S, Totland GK, Wargelius A, Hansen T. (2005). Vertebrae of the trunk and tail display different growth rates in response to photoperiod in Atlantic salmon, Salmo salar L., post-smolts. Aquaculture 250:516-524.

Folmar LC, Dickhoff WW. (1980). The parr-smolt transformation (smoltification) and seawater adaptation in salmonids-a review of selected literature. Aquaculture 21:1-37.

Gamperl AK, Vijayan MM, Boutilier RG. (1994). Experimental control of stress hormone levels in fishes-techniques and applications. Rev. Fish Biol. Fish 4:215-255.

Hirayama J, Kaneko M, Cardone L, Cahill G, Sassone-Corsi P. (2005). Analysis of circadian rhythms in zebrafish. Methods Enzymol. 393:186-204.

Hoar WS. (1988). The physiology of smolting. In Hoar WS, Randall DJ (eds.). Fish physiology. Fish Physiol. 11B. Academic Press, NY:275-343. 
Huang TS, Grodeland G, Sleire L, Wang MY, Kvalheim G, Laerum OD. (2009). Induction of circadian rhythm in cultured human mesenchymal stem cells by serum shock and cAMP analogs in vitro. Chronobiol. Int. 26:242-57.

Iigo M, Hara M, Ohtani-Kaneko R, Hirata K, Tabata M, Aida K. (1997). Photic and circadian regulations of melatonin rhythms in fishes. Biol. Signals 6:225-232.

Iigo M, Abe T, Kambayashi S, Oikawa K, Masuda T, Mizusawa K, Kitamura S, Azuma T, Takagi Y, Aida K, Yanagisawa T. (2007). Lack of circadian regulation of in vitro melatonin release from the pineal organ of salmonid teleosts. Gen. Comp. Endocrinol. 154:91-97.

Johnston IA, Manthri S, Smart A, Campbell P, Nickell D, Alderson R. (2003). Plasticity of muscle fibre number in seawater stages of Atlantic salmon in response to photoperiod manipulation. $J$. Exp. Biol. 206:3425-3435.

Kobayashi Y, Ishikawa T, Hirayama J, Daiyasu H, Kanai S, Toh H, Fukuda I, Tsujimura T, Terada N, Kamei Y, Yuba S, Iwai S, Todo T. (2000). Molecular analysis of zebrafish photolyase/cryptochrome family: two types of cryptochromes present in zebrafish. Genes Cells 5:725-38.

Koukkari WL, Sothern RB. (2006). Introducing biological rhythms. New York: Springer.

Krakenes R, Hansen T, Stefansson SO, Taranger GL. (1991). Continuous light increases growth-rate of Atlantic salmon (Salmo salar L.) postsmolts in sea cages. Aquaculture 95:281-287.

Lahiri K, Vallone D, Gondi SB, Santoriello C, Dickmeis T, Foulkes NS. (2005). Temperature regulates transcription in the zebrafish circadian clock. PLoS Biol. 3:pe351.

Li YY, Takei Y. (2003). Ambient salinity-dependent effects of homologous natriuretic peptides (ANP, VNP, and CNP) on plasma cortisol level in the eel. Gen. Comp. Endocrinol. 130:317-323.

Lowrey PL, Takahashi JS. (2000). Genetics of the mammalian circadian system: photic entrainment, circadian pacemaker mechanisms, and posttranslational regulation. Annu. Rev. Genet. 34:533-562.

Mayer I. (2000). Effect of long-term pinealectomy on growth and precocious maturation in Atlantic salmon, Salmo salar parr. Aquat. Liv. Res. 13:139-144.

McCormick SD. (2001). Endocrine control of osmoregulation in teleost fish. Am. Zool. 41:781-794.

McCormick SD, Saunders RL, Henderson EB, Harmon PR. (1987). Photoperiod control of parrsmolt transformation in Atlantic salmon (Salmo-Salar)—changes in salinity tolerance, gill $\mathrm{Na}^{+}, \mathrm{K}^{+}$-ATPase activity, and plasma thyroid-hormones. Can. J. Fish. Aquat. Sci. 44:1462-1468.

McCormick SD, Hansen LP, Quinn TP, Saunders RL. (1998). Movement, migration, and smolting of Atlantic salmon (Salmo salar). Can. J. Fish. Aquat. Sci. 55:77-92.

Mendez-Ferrer S, Lucas D, Battista M, Frenette PS. (2008). Haematopoietic stem cell release is regulated by circadian oscillations. Nature 452:442-447.

Migaud H, Davie A, Chavez CCM, Al-Khamees S. (2007). Evidence for differential photic regulation of pineal melatonin synthesis in teleosts. J. Pineal Res. 43:327-335.

Migaud H, Davie A, Taylor JF. (2010). Current knowledge on the photoneuroendocrine regulation of reproduction in temperate fish species. J. Fish Biol. 76:27-68.

Nordgarden U, Oppedal F, Taranger GL, Hemre GI, Hansen T. (2003a). Seasonally changing metabolism in Atlantic salmon (Salmo salar L.) I-growth and feed conversion ratio. Aquac. Nutr. 9:287-293.

Nordgarden U, Torstensen BE, Froyland L, Hansen T, Hemre GI. (2003b). Seasonally changing metabolism in Atlantic salmon (Salmo salar L.) II-beta-oxidation capacity and fatty acid composition in muscle tissues and plasma lipoproteins. Aquac. Nutr. 9:295-303.

Nordgarden U, Hansen T, Hemre GI, Sundby A, Bjornsson BT. (2005). Endocrine growth regulation of adult Atlantic salmon in seawater: the effects of light regime on plasma growth hormone, insulin-like growth factor-I, and insulin levels. Aquaculture 250:862-871.

Oppedal F, Juell JE, Taranger GL, Hansen T. (2001). Artificial light and season affects vertical distribution and swimming behaviour of post-smolt Atlantic salmon in sea cages. J. Fish Biol. 58:1570-1584.

Pando MP, Pinchak AB, Cermakian N, Sassone-Corsi P. (2001). A cell-based system that recapitulates the dynamic light-dependent regulation of the vertebrate clock. Proc. Natl. Acad. Sci. U. S. A. 98:10178-10183.

Park JG, Park YJ, Sugama N, Kim SJ, Takemura A. (2007). Molecular cloning and daily variations of the Period gene in a reef fish Siganus guttatus. J. Comp. Physiol. A Neuroethol. Sens. Neural Behav. Physiol. 193:403-411. 
Pavlidis M, Greenwood L, Paalavuo M, Molsa H, Laitinen JT. (1999). The effect of photoperiod on diel rhythms in serum melatonin, cortisol, glucose, and electrolytes in the common dentex, Dentex dentex. Gen. Comp. Endocrinol. 113:240-250.

Pickering AD, Pottinger TG. (1983). Seasonal and diel changes in plasma-cortisol levels of the brown trout, Salmo trutta L. Gen. Comp. Endocrinol. 49:232-239.

Portaluppi F, Touitou Y, Smolensky MH. (2008). Ethical and methodological standards for laboratory and medical biological rhythm research. Chronobiol. Int. 25:999-1016.

Pottinger TG, Carrick TR, Appleby A, Yeomans WE. (2000). High blood cortisol levels and low cortisol receptor affinity: is the Chub, Leuciscus cephalus, a cortisol-resistant teleost? Gen. Comp. Endocrinol. 120:108-117.

Ralph MR, Foster RG, Davis FC, Menaker M. (1990). Transplanted suprachiasmatic nucleus determines circadian period. Science 247:975-978.

Randall CF, Bromage NR, Thorpe JE, Miles MS, Muir JS. (1995). Melatonin rhythms in Atlantic salmon (Salmo salar) maintained under natural and out-of-phase photoperiods. Gen. Comp. Endocrinol. 98:73-86.

Rousseau K, Atcha Z, Loudon AS. (2003). Leptin and seasonal mammals. J. Neuroendocrinol. 15:409-414.

Saunders RL, Henderson EB. (1988). Effects of constant day length on sexual-maturation and growth of Atlantic salmon (Salmo-Salar) parr. Can. J. Fish. Aquat. Sci. 45:60-64.

Simonneaux V, Poirel VJ, Garidou ML, Nguyen D, Diaz-Rodriguez E, Pevet P. (2004). Daily rhythm and regulation of clock gene expression in the rat pineal gland. Mol. Brain Res. 120:164-172.

Stefansson SO, Bjornsson BT, Hansen T, Haux C, Taranger GL, Saunders RL. (1991). Growth, parrsmolt transformation, and changes in growth-hormone of Atlantic salmon (Salmo-Salar) reared under different photoperiods. Can. J. Fish. Aquat. Sci. 48:2100-2108.

Stefansson SO, Nilsen TO, Ebbesson LOE, Wargelius A, Madsen SS, Bjornsson BT, McCormick SD. (2007). Molecular mechanisms of continuous light inhibition of Atlantic salmon parr-smolt transformation. Aquaculture 273:235-245.

Storch KF, Lipan O, Leykin I, Viswanathan N, Davis FC, Wong WH, Weitz CJ. (2002). Extensive and divergent circadian gene expression in liver and heart. Nature 417:78-83.

Taranger GL, Haux C, Stefansson SO, Bjornsson BT, Walther BT, Hansen T. (1998). Abrupt changes in photoperiod affect age at maturity, timing of ovulation and plasma testosterone and oestradiol-17 beta profiles in Atlantic salmon, Salmo salar. Aquaculture 162:85-98.

Taylor JF, Migaud H, Porter MJR, Bromage NR. (2005). Photoperiod influences growth rate and plasma insulin-like growth factor-I levels in juvenile rainbow trout, Oncorhynchus mykiss. Gen. Comp. Endocrinol. 142:169-185.

Thorpe JE, McConway MG, Miles MS, Muir JS. (1987). Diel and seasonal changes in resting plasma cortisol levels in juvenile Atlantic salmon, Salmo salar L. Gen. Comp. Endocrinol. 65:19-22.

Tomita T, Miyazaki K, Onishi Y, Honda S, Ishida N, Oishi K. (2010). Conserved amino acid residues in C-terminus of PERIOD 2 are involved in interaction with CRYPTOCHROME 1. Biochim. Biophys. Acta 1803:492-498.

Vallone D, Gondi SB, Whitmore D, Foulkes NS. (2004). E-box function in a period gene repressed by light. Proc. Natl. Acad. Sci. U. S. A. 101:4106-4111.

Vandesompele J, De Preter K, Pattyn F, Poppe B, Van Roy N, De Paepe A, Speleman F. (2002). Accurate normalization of real-time quantitative RT-PCR data by geometric averaging of multiple internal control genes. Genome Biol. 3:RESEARCH0034.

Velarde E, Haque R, Iuvone PM, Azpeleta C, Alonso-Gomez AL, Delgado MJ. (2009). Circadian clock genes of goldfish, Carassius auratus: cDNA cloning and rhythmic expression of Period and Cryptochrome transcripts in retina, liver, and gut. J. Biol. Rhythms 24:104-113.

Wang H. (2008). Comparative analysis of Period genes in teleost fish genomes. J. Mol. Evol. 67:29-40.

Wiik R, Andersen K, Uglenes I, Egidius E. (1989). Cortisol-induced increase in susceptibility of Atlantic salmon, Salmo salar, to Vibrio salmonicida, together with effects on the blood cell pattern. Aquaculture 83:201-215.

Ziv L, Gothilf Y. (2006). Period2 expression pattern and its role in the development of the pineal circadian clock in zebrafish. Chronobiol. Int. 23:101-112. 